\title{
Optimum growth rate of Belgian Blue double-muscled replacement heifers
}

\author{
L.O. Fiems ${ }^{\#}$ and D.L. De Brabander \\ Institute for Agricultural and Fisheries Research (ILVO), Animal Sciences, \\ Scheldeweg 68, 9090 Melle, Belgium
}

\begin{abstract}
Belgian Blue double-muscled (BBDM) heifers $(n=341)$ were used to investigate the effect of body weight (BW) at first calving at an age of two years (BWC). Females with a birth weight (BWB) $<40 \mathrm{~kg}$ realized a lower body weight gain (BWG) up to an age of four months and they also had a significant lower BWC. Dams with a higher BWC gave birth to calves with a higher birth weight. Milk yield during the first four months after calving linearly increased with a significantly higher BWC $\left(\mathrm{R}^{2}=0.34\right)$. Females with a daily BWG from zero to four months of age of $<0.6 \mathrm{~kg}$ have a lower BWC than females with a higher growth rate. A higher rate of gain from zero to four months did not affect subsequent heifer BWG. There was a tendency for a BW-loss during the last trimester of the gestation when BW at conception was lower, especially when this period coincided with the grazing season. This may be due to a reduced intake capacity of BBDM animals and a heavy BWB of the offspring. With mean adult BW of BBDM cows of $c a .710 \mathrm{~kg}$, heifers should gain approximately $0.8 \mathrm{~kg} / \mathrm{d}$ from birth to conception, to achieve $55-60 \%$ of their adult BW at the conception at 15 months of age. A lower BWC was only partly compensated from the first up to the third calving, but there was no clear effect on the interval from the first to the third calving. From the present study we can conclude that it is desirable to strive for a pre-partum BW of about $600 \mathrm{~kg}$ in BBDM heifers when their first calving occurs at an age of 24 months. Extra attention should be paid to the nutrition of BBDM heifers to realize an accelerated growth rate before they become pregnant.
\end{abstract}

Keywords: Belgian Blue; double-muscling; replacement heifers; first calving; body weight

${ }^{\#}$ Corresponding author. E-mail: leo.fiems@ilvo.vlaanderen.be

\section{Introduction}

It is advised to let Holstein replacement heifers calve at 22 to 24 months of age with an adequate body size to ensure an acceptable first lactation performance (Hoffmann, 1997). Beef producers should also aim to let their replacement heifers calve at two years of age. This practice will improve the profitability of the beef operation by offsetting the high costs of feed, labour and investment in raising heifers. NRC (2000) mentions a target breeding weight of $55-65 \%$ of mature weight for beef heifers. It is not clear if extremely meaty and late maturing BBDM heifers can have their first parturition at two years, and what growth pattern is desirable. This report deals with the effect of BW at first calving on milk production, birth weight of the offspring, calving interval and further development, and tries to deduce an optimum BW.

\section{Materials and Methods}

Data were collected from 341 heifers that were born and calved at the institute. Most of the heifers had a rearing period of five months. They received a milk diet at $10 \%$ of their body weight and were weaned when concentrate intake reached $0.5-0.75 \mathrm{~kg}$ daily. Some of the heifers were suckled by their dams for four to five months. They were turned out on pasture after the rearing period or in springtime, receiving a supplement of sugar beet pulp and soyabean meal up to four kg per day during the first year and two $\mathrm{kg}$ sugar beet pulp during the second year. Indoor feeding was based on maize and grass silage fed ad libitum, supplemented with a limited supply of an appropriate concentrate. A bull was put with the heifers for natural service. Age at first calving averaged $790 \pm 86$ days.

The heifers were divided into four groups according to their $\mathrm{BW}$ before calving $\left(\mathrm{BW}_{\mathrm{BC}}\right)$ : $\leq 550,551$ $600,601-650$ and $>650 \mathrm{~kg}$. The effect of $\mathrm{BW}_{\mathrm{BC}}$ on performance was investigated, using age at first calving as a covariate. Calf gender was also used as covariate when birth weight of the offspring was studied. Heifers confined indoors or on pasture during the last 100 days of gestation were considered as two subgroups, to study BW evolution. Body weight at 100 days prior to calving was corrected for the conceptus, using the 
equation of Ferrell et al. (1976), modified for BBDM animals. Furthermore, the impact of heifer birth weight and $\mathrm{BWG}$ during the first four months of life on $\mathrm{BW}_{\mathrm{BC}}$ was analysed. Heifers were divided into four groups, according to their birth weight $<35,35-45,46-55$ and $>55 \mathrm{~kg}$, and their daily BWG $<0.6,0.6-0.75,0.75-$ 0.9 and $>0.9 \mathrm{~kg}$. The effect of $\mathrm{BW}_{\mathrm{BC}}$ was studied using analysis of variance, analysis of covariance and regression analysis. Results were given as least square means.

\section{Results and Discussions}

The impact of $\mathrm{BW}_{\mathrm{BC}}$ is shown in Table 1. Body weight at conception and $\mathrm{BWG}$ during the last 100 days of gestation were also different. All cows, except those with $\mathrm{BW}_{\mathrm{BC}}>650 \mathrm{~kg}$, lost weight, and $\mathrm{BW}$ loss was higher when $\mathrm{BW}_{\mathrm{BC}}$ was lower. This phenomenon may be explained by the fact that calf birth weight amounted to $9.7 \%$ of pre-calving $\mathrm{BW}\left(\mathrm{BW}_{\mathrm{AC}}\right)$ for heifers with a $\mathrm{BW}_{\mathrm{BC}}<550 \mathrm{~kg}$ against $8.2 \%$ for heifers with a $\mathrm{BW}_{\mathrm{BC}}>650 \mathrm{~kg}(\mathrm{P}=0.017)$. Heavier females with a lower calf birth weight to dam weight ratio may be favourable to reduce the occurrence of dystocia (Morrison et al., 1989). The ratio of calf birth weight to $\mathrm{BW}_{\mathrm{AC}}$ was considerably higher than in Holstein primiparous $(7.5 \%)$ or multiparous $(6.5 \%)$ cows (Johanson $\&$ Berger, 2003). The ratio of calf birth weight to $\mathrm{BW}_{\mathrm{BC}}$ was comparable with the ratios for crossbred cows (8.4 - 9.6\%) with varying age (Morrison et al., 1989). Body weight loss was higher when calving occurred at the end of the summer period (August - October) than at the end of the winter period (February - April), with a tendency for an interaction between $\mathrm{BW}_{\mathrm{BC}}$ group and period of calving $(\mathrm{P}=0.11)$. However, there was no effect on birth weight of the offspring $(\mathrm{P}=0.395)$. The low BWG may be explained in general by the lower intake in late pregnancy due to a compression of the rumen by the growing uterus (Forbes, 1995), and the lower intake capacity which is typical for BBDM animals (Fiems et al., 1997). The lower BWG during the summer period can be explained by the lower dry matter content of grass compared to the diet fed during the indoor period.

Table 1 Effect of body weight at first calving on the performance of Belgian Blue double-muscled heifers

\begin{tabular}{|c|c|c|c|c|c|}
\hline $\mathrm{BW}_{\mathrm{BC}}(\mathrm{kg})$ & $\leq 550$ & $551-600$ & $601-650$ & $>650$ & Pooled SD \\
\hline $\begin{array}{l}\text { Number of heifers } \\
\mathrm{BW}_{\mathrm{BC}}(\mathrm{kg})\end{array}$ & $\begin{array}{c}35 \\
523^{\mathrm{a}}\end{array}$ & $\begin{array}{c}129 \\
577^{\mathrm{b}}\end{array}$ & $\begin{array}{l}121 \\
622^{\mathrm{c}}\end{array}$ & $\begin{array}{c}56 \\
687^{\mathrm{d}}\end{array}$ & 58 \\
\hline $\begin{array}{l}\text { Reproduction } \\
\text { BW at conception }(\mathrm{kg}) \\
\text { 100d pre-calving BWG }(\mathrm{kg} / \mathrm{d})\end{array}$ & $\begin{array}{c}393^{\mathrm{a}} \\
-0.30^{\mathrm{a}}\end{array}$ & $\begin{array}{c}411^{\mathrm{b}} \\
-0.20^{\mathrm{b}}\end{array}$ & $\begin{array}{l}432^{\mathrm{c}} \\
-0.13^{\mathrm{bc}}\end{array}$ & $\begin{array}{l}454^{\mathrm{d}} \\
0.05^{\mathrm{c}}\end{array}$ & $\begin{array}{c}33 \\
0.37\end{array}$ \\
\hline $\begin{array}{l}\text { August-October } \\
\text { February-April }\end{array}$ & $\begin{array}{l}-0.37^{\mathrm{a}}{ }_{(8)} \\
-0.11^{\mathrm{a}}{ }_{(24)}\end{array}$ & $\begin{array}{l}-0.52^{\mathrm{a}}{ }^{(23)} \\
\left.0.10^{\mathrm{b}}{ }_{(46)}\right)\end{array}$ & $\begin{array}{c}-0.50^{\mathrm{a}}{ }_{(23)} \\
0.08^{\mathrm{b}}{ }_{(43)}\end{array}$ & $\begin{array}{l}-0.35^{\mathrm{a}}{ }_{(15)} \\
0.19^{\mathrm{b}}{ }_{(24)}\end{array}$ & $\begin{array}{l}0.31 \\
0.29\end{array}$ \\
\hline $\begin{array}{l}\text { Calf birth wt. }(\mathrm{kg})^{*} \\
\text { Calf birth wt. }\left(\% \mathrm{BW}_{\mathrm{BC}}\right)^{*} \\
\text { Calf birth wt. }\left(\% \mathrm{BW}_{\mathrm{AC}}\right)^{*} \\
\text { Calving interval (d) }\end{array}$ & $\begin{array}{l}43^{\mathrm{a}} \\
8.2^{\mathrm{a}} \\
9.7^{\mathrm{a}} \\
390^{\mathrm{a}}\end{array}$ & $\begin{array}{r}45^{\mathrm{b}} \\
7.9^{\mathrm{a}} \\
9.3^{\mathrm{a}} \\
402^{\mathrm{a}}\end{array}$ & $\begin{array}{l}47^{\mathrm{c}} \\
7.6^{\mathrm{b}} \\
8.9^{\mathrm{b}} \\
400^{\mathrm{a}}\end{array}$ & $\begin{array}{l}48^{\mathrm{c}} \\
7.1^{\mathrm{c}} \\
8.2^{\mathrm{c}} \\
407^{\mathrm{a}}\end{array}$ & $\begin{array}{l}7 \\
1.1 \\
1.5 \\
22\end{array}$ \\
\hline $\begin{array}{l}\text { Lactation } \\
\mathrm{BW}_{\mathrm{BC}}(\mathrm{kg}) \\
\mathrm{BW}_{\mathrm{AC}}(\mathrm{kg}) \\
\text { Milk yield }(\mathrm{kg} / \mathrm{d})\end{array}$ & $\begin{array}{l}(7) \\
545^{\mathrm{a}} \\
465^{\mathrm{a}} \\
5.0^{\mathrm{a}}\end{array}$ & $\begin{array}{l}(11) \\
570^{\mathrm{b}} \\
489^{\mathrm{b}} \\
5,9^{\mathrm{ab}}\end{array}$ & $\begin{array}{l}(13) \\
626^{\mathrm{c}} \\
541^{\mathrm{c}} \\
5,6^{\mathrm{a}}\end{array}$ & $\begin{array}{l}(10) \\
699^{\mathrm{d}} \\
608^{\mathrm{d}} \\
7,2^{\mathrm{b}}\end{array}$ & $\begin{array}{l}20 \\
27 \\
1.5\end{array}$ \\
\hline $\begin{array}{l}\text { Further development } \\
\text { BW after } 3^{\text {rd }} \text { calving }(\mathrm{kg}) \\
\text { BWG } 1^{\text {st }} 3^{\text {rd }} \text { calving }(\mathrm{kg} / \mathrm{d}) \\
\text { Age at } 3^{\text {rd }} \text { calving }(\mathrm{d})\end{array}$ & $\begin{array}{l}(23) \\
618^{\mathrm{a}} \\
0.20^{\mathrm{a}} \\
1667^{\mathrm{a}}\end{array}$ & $\begin{array}{c}(61) \\
640^{\mathrm{a}} \\
0.18^{\mathrm{ab}} \\
1623^{\mathrm{ab}}\end{array}$ & $\begin{array}{c}(74) \\
665^{\mathrm{b}} \\
0.16^{\mathrm{bc}} \\
1645^{\mathrm{ab}}\end{array}$ & $\begin{array}{l}(44) \\
696^{\mathrm{c}} \\
0.14^{\mathrm{c}} \\
1612^{\mathrm{b}}\end{array}$ & $\begin{array}{c}56 \\
0.07 \\
93\end{array}$ \\
\hline
\end{tabular}

\footnotetext{
${ }^{\mathrm{ab}}$ Values with a same superscript are not significantly different $(\mathrm{P}>0.05)$.

() Number of females. * Gender as covariate.

$\mathrm{BW}_{\mathrm{BC}}-$ Body weight before calving; $\mathrm{BW} \mathrm{AC}_{\mathrm{C}}$ - Body weight after calving.
} 
Birth weight of the offspring, adjusted for gender, increased with increasing $\mathrm{BW}_{\mathrm{BC}}$ up to $600 \mathrm{~kg}$, while it decreased when expressed as a percentage of $\mathrm{BW}_{\mathrm{BC}}$ or $\mathrm{BW}_{\mathrm{AC}}$. The larger $\mathrm{BW}$ loss in lighter heifers may have provoked some nutritional stress for the foetus, which can result in a reduced growth potential (Greenwood \& Café, 2007). Nevertheless, calf birth weight expressed as a percentage of dam BW was higher in lighter than in heavier heifers. Interval from the first to the second calving was not affected by $\mathrm{BW}_{\mathrm{BC}}$. Although the number of suckling heifers was limited, because BBDM dams do not always suckle their offspring, milk yield, using the weighing-suckling-weighing technique, was higher for heavier heifers $(\mathrm{P}<0.001)$. Milk production correlated better with $\mathrm{BW}_{\mathrm{AC}}$ than $\mathrm{BW}_{\mathrm{BC}}$. For each $\mathrm{kg}$ extra $\mathrm{BW}_{\mathrm{AC}}$ milk yield raised by $17 \mathrm{~g}$. As BWG of the suckling calves is closely related $(\mathrm{r}=0.807)$ to the milk production of the dam (Fiems et al., 2008), a higher $\mathrm{BW}_{\mathrm{BC}}$ is desirable.

Cows that calved up to three times were heavier at the third calving when $\mathrm{BW}_{\mathrm{BC}}$ was higher. Nevertheless, lighter primiparous cows realized a significantly higher BWG from the first to the third calving, which is in line with the findings of Greenwood \& Café (2007). There is a tendency that age at the third calving was somewhat lower when $\mathrm{BW}_{\mathrm{BC}}$ was higher, which may be an indication of shorter calving intervals in these females.

No exact data concerning the effect of $\mathrm{BW}_{\mathrm{BC}}$ on calf mortality are available, but primiparous cows with a lower $\mathrm{BW}_{\mathrm{BC}}$ generally have a lower body condition, as found in a previous study (Fiems et al., 2009). A good correlation was also found between BW and body condition on the one hand (Fiems et al., 2006), and between body condition of the dam and calf survival (Fiems et al., 2009). These results can be explained by the findings of Odde et al. (1986), showing increased volume of colostrum, increased calf vigour and increased ability of the calf to absorb immunoglobulins when heifers are in a better condition.

Although only one breeding bull was used, heifers with a lower $\mathrm{BW}_{\mathrm{BC}}$ gave birth to significantly lighter calves. We found a correlation of 0.267 and $0.233(\mathrm{P}<0.01)$ between dam birth weight and birth weight of the male and the female offspring, respectively. This correlation is of the same magnitude as those found by Lamb \& Barker (1975) in Holsteins. It is known that calves with a heavier birth weight result in heavier animals later on (Dawson et al., 1947). Furthermore, animals with a very low birth weight never catch up this retarded development (Greenwood et al., 2006; Greenwood \& Cafe, 2007). A rearrangement of the data from dams with a birth weight $<40 \mathrm{~kg}$ or $\geq 40 \mathrm{~kg}$ showed that $\mathrm{BW}_{\mathrm{BC}}$, initial BWG and birth weight of the offspring were significantly different. It is remarkable that a lower birth weight also resulted in a slower gain during the first months of life. A lower prenatal gain beside a genetic influence cannot be excluded. As a consequence of the lower intake capacity and a high birth weight of BBDM animals, pregnant heifers appear to be more susceptible to nutritional stress than cows with a normal conformation.

Body weight gain of $<0.6 \mathrm{~kg}$ up to four months of age resulted in heifers with a lower $\mathrm{BW}_{\mathrm{BC}}$. This finding agrees with results from Heinrichs et al. (2005). Although BWG up to four months was different between groups, $\mathrm{BW}_{\mathrm{BC}}$ was not different between groups with a $\mathrm{BWG}>0.6 \mathrm{~kg}$. Cattle have the ability to compensate for some growth retardation. However, if this retardation occured early in life, it may be difficult to compensate afterwards (Berge, 1991). A weak correlation between birth weight and BWG up to four months was found $(r=0,174 ; \mathrm{P}=0,001)$. Consequently, lighter calves do not realize a high BWG.

Based on the positive relationship of $\mathrm{BW}_{\mathrm{BC}}$ on $\mathrm{BWG}$ towards the end of gestation, calf birth weight, milk yield and development until the third parturition we may deduce that a $\mathrm{BW}_{\mathrm{BC}}$ of $600 \mathrm{~kg}$ seems desirable (Table 2).

This BW corresponds to $85 \%$ of the adult BW and is in agreement with Engelken (2008), who proposed that beef heifers should reach $85 \%$ of their expected mature weight by the time they calve. Taking into account that BWG during the first four months of life should be more than $0.6 \mathrm{~kg}$, and that a minimal BW at conception of $55-60 \%$ of mature BW should be obtained, we tried to find out the optimal BWG from birth to calving at \pm 24 months, which is shown in Table 2. Mature BW of the BBDM herd of the institute was estimated at $\pm 710 \mathrm{~kg}$. We propose a BWG of $750 \mathrm{~g} / \mathrm{d}$ during the rearing period, but it may be interesting if a higher BWG could be realized to make it easier to obtain the target BW at the start of the gestation. Because BWG during the last months of gestation is low, $\mathrm{BW}_{\mathrm{AC}}$ should be attained at an age of 21 months. This means a BWG of $720 \mathrm{~g} / \mathrm{d}$ from birth to 21 months. This growth rate necessitates an intensive management with regard to forage production, feeding, hygiene and reproduction. The implications of a higher $\mathrm{BW}_{\mathrm{BC}}$ on the nutritional requirements and the economical consequences are not yet known. 
Table 2 Optimal body weight gain of Belgian Blue replacement heifers

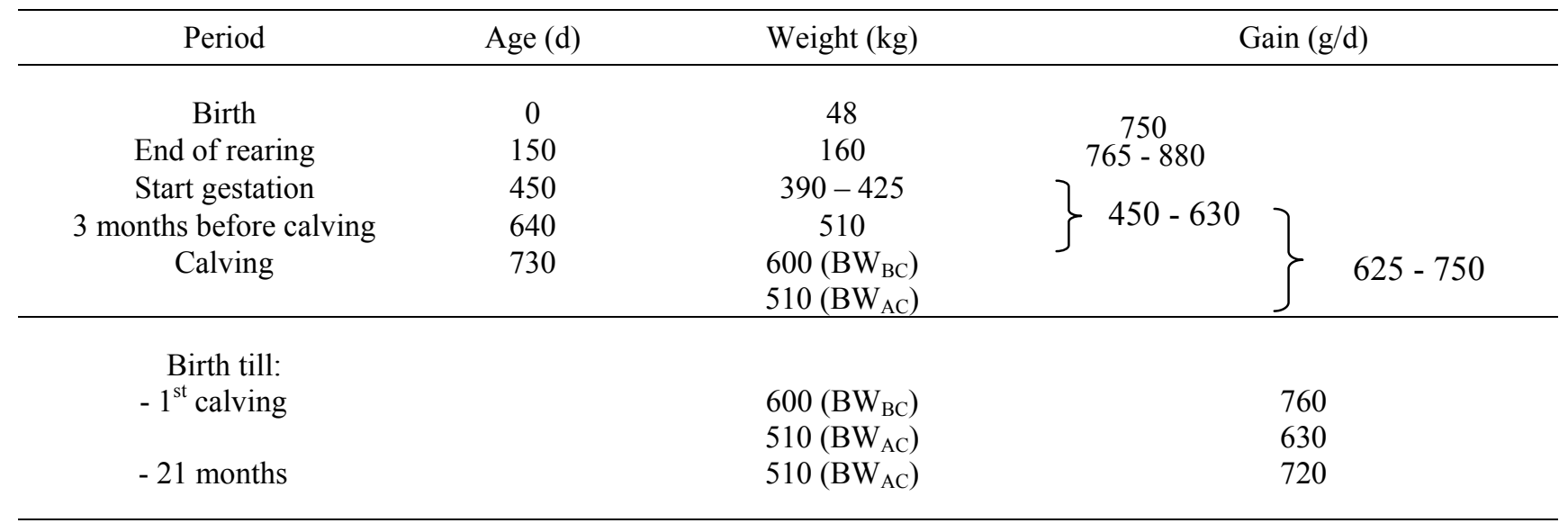

\section{Conclusion}

The present findings indicate that a $\mathrm{BW}_{\mathrm{BC}}$ at an age of two years of $600 \mathrm{~kg}$ should be advised for BBDM heifers. This corresponds with a BWG of $760 \mathrm{~g} / \mathrm{d}$ from birth to calving at 24 months.

\section{References}

Berge, P., 1991. Long-term effects of feeding during calfhood on subsequent performance in beef cattle (a review). Livest. Prod. Sci. 28, 179-201.

Dawson, W.M., Phillips, R.W. \& Black, W.H., 1947. Birth weight as a criterion of selection in beef cattle. J. Anim. Sci. 6, 247-257.

Engelken, T.J., 2008. Developing replacement beef heifers. Theriogenology 70, 569-572.

Ferrell, C.L., Garrett, W.N. \& Hinman, N., 1976. Growth, development and composition of the udder and gravid uterus of beef heifers during pregnancy. J. Anim. Sci. 42, 1477-1489.

Fiems, L.O., Cottyn, B.G., Boucqué, C.V., Bogaerts, D.F., Van Eenaeme, C. \& Vanacker, J.M., 1997. Effect of beef type, body weight and dietary protein content on digestibility, voluntary feed intake, blood and urine metabolites and nitrogen retention. J. Anim. Physiol. Anim. Nutr. 77, 1-9.

Fiems, L.O., De Campeneere, S., De Boever, J.L., Van Caelenbergh, W. \& De Brabander, D.L., 2009. Effect of indoor energy restriction level and management on beef production in Belgian Blue double-muscled cow-calf pairs. J. Anim. Physiol. Anim. Nutr. (In press).

Fiems, L.O., Van Caelenbergh, W., De Campeneere, S. \& De Brabander, D.L., 2006. Body condition scoring in relation to changes in body weight and performance in Belgian Blue double-muscled beef cows. Anim. Res. 55, 121-130.

Fiems, L.O., Van Caelenbergh, W., De Campeneere, S. \& De Brabander, D.L., 2008. Effect of dam factors on milk intake and performance of Belgian Blue suckling calves. Animal 2, 135-140.

Forbes, J.M., 1995. Voluntary food intake and diet selection in farm animals. CAB International, Oxon, UK.

Greenwood, P.L. \& Café, L.M., 2007. Prenatal and pre-weaning growth and nutrition of cattle: long-term consequences for beef production. Animal 1, 1283-1296.

Greenwood, P.L., Cafe, L.M., Hearnshaw, H., Hennessy, D.W., Thompson \& J.M., Morris, S.G., 2006. Long-term consequences of birth weight and growth to weaning on carcass, yield and beef quality characteristics of Piedmontese- and Wagyu-sired cattle. Aust. J. Exp. Agric. 46, 257-269.

Heinrichs, A.J., Heinrichs, B.S., Harel, O., Rogers, G.W. \& Place, N.T., 2005. A prospective study of calf factors affecting age, body size, and body condition score at first calving of Holstein dairy heifers. J. Dairy Sci. 88, 2828-2835.

Hoffmann, P.C., 1997. Optimum body size of Holstein replacement heifers. J. Anim. Sci. 75, 836-845.

Johanson, J.M. \& Berger, P.J., 2003. Birth weight as a predictor of calving ease and perinatal mortality in Holstein cattle. J. Dairy Sci. 86, 3745-3755.

Lamb, R.C. \& Barker, B.O., 1975. Genetic relationship between birth weight and adult weight in Holsteins. J. Dairy Sci. 58, 724-728. 
Morrison, D.G., Humes, P.E. \& Koonce, K.L., 1989. Comparisons of Brahman and continental European crossbred cows for calving ease in a subtropical environment. J. Anim. Sci. 67, 1722-1731.

NRC, 2000. Nutrient Requirements of Beef Cattle. $7^{\text {th }}$ Revised Edition, National Research Council, Washington D.C., USA.

Odde, K.G., Abernathy, L.A. \& Greathouse, G.A., 1986. Effect of body condition and calving difficulty on calf vigor and calf serum immunoglobulin concentrations in two-year-old beef heifers. Colorado State University, Fort Collins, Beef Program Report. 